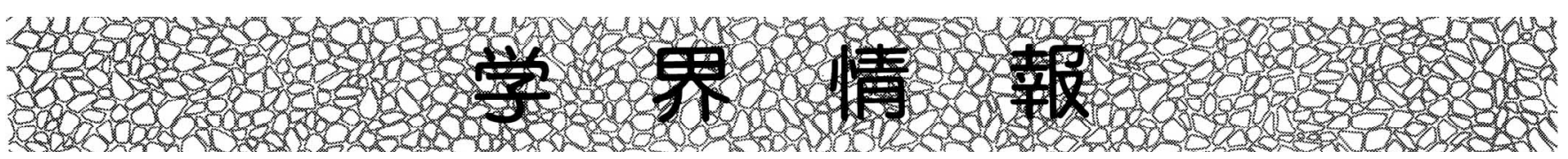

\title{
X SIPDA (International Symposium on Lightning Protection) 報告
}

2009 年 11 月 9 日から 11 月 13 日までの 5 日間, ブラジ ルのクリチバで第 10 回目の International Symposium on Lightning Protection (Simpósio Internacional de Proteção Contra Descargas Atmosféricas:SIPDA）が，クリケバ市内 の Estação Embratel コンベンションセンター（図 1 : 左写 真）で開催された。SIPDA は，雷放電，落雷位置標定，送 配電設備の雷保護, 通信設備・構造物の雷保護等, 雷に関 する最新の研究成果について情報交換することを目的とし た国際会議である。本国際会議は，サンパウロ大学が中心 となり IEEE との共催によって隔年で開催されている。現 在, 東京大学の石井教授と電力中央研究所の横山氏が International Steering Committee を務めている。ブラジ ルでは，雷現象と接地に関する国際会議（International Conference on Lightning Physics and Effects \& International Conference on Grounding and Earthing) も隔年で SIPDA と交互に開催されていることから，毎年雷 に関連する国際会議がおこなわれている。会場となったク リチバ (図 1 : 右写真) は, ブラジル南部では最大の都市で, パラナ州の州都である。ブラジルの中では比較的治安が良 く, 南米で最も整備された都市として知られている。現在 の人口は，170万人程度であり，サンパウロに次いで日系人 が多い都市で，その数は 3 万人に及ぶ。

本国際会議は，Invited Lecture（招待講演）と Technical Session（一般講演）に大別され，世界 28 ケ国から約 200 名の参加があった。招待講演は, 各分野の著名な 8 名の研 究者によっておこなわれ, 日本からも電力中央研究所の横 山氏が，“風車の雷害対策と冬季雷の特性”について講演さ れた。この招待講演は，通常の論文発表とは異なり 1 件当 たり 75 分が割り当てられ, 聴講者からの質問や意見交換が

\section{表 1 一般講演の発表論文数}

\begin{tabular}{|l|c|}
\hline \multicolumn{1}{|c|}{ セッション 論文数 } \\
\hline Lightning Characteristics and Modeling & 18 \\
\hline Lightning Protection of Structures & 9 \\
\hline Grounding & 11 \\
\hline Lightning Detection and Location Systems & 7 \\
\hline Lightning Strikes to Tall Structures & 5 \\
\hline Lightning Electromagnetic Fields & 10 \\
\hline $\begin{array}{l}\text { Lightning Protection of Medium and Low } \\
\text { Voltage Lines }\end{array}$ & 12 \\
\hline $\begin{array}{l}\text { Lightning Protection of Substations and } \\
\text { Transmission Lines }\end{array}$ & 7 \\
\hline $\begin{array}{l}\text { Surge Arresters and Surge Protective } \\
\text { Devices }\end{array}$ & 5 \\
\hline Miscellaneous 合計 & 7 \\
\hline \multicolumn{1}{|c|}{} & 91 \\
\hline
\end{tabular}

(C) 2010 The Institute of Electrical Engineers of Japan.
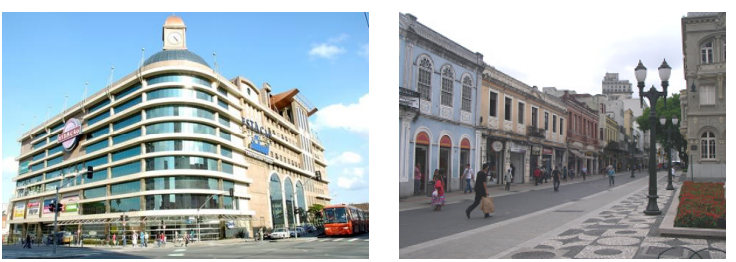

図 1 会場となったクリチバの写真

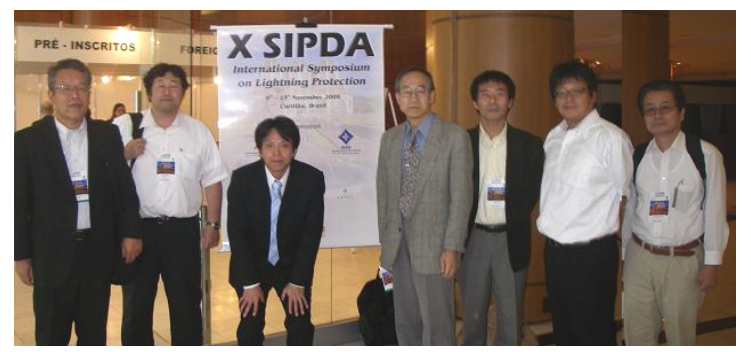

図2 日本からの参加者

活発におこなわれた。このように多くの招待講演をプログ ラムに組み込んで活発な討論がなされる国際会議は, 他に はあまり見られず，本国際会議の特徵とも言える。また，

一般講演については, 表 1 に示寸通り, 10 のセッションに 区分され，オーラル，ポスターを含め計 91 件の論文発表が あった。内訳として 42 件がブラジル国内からの発表であり， その他は世界 18 ケ国の研究者による発表であった。ブラジ ル国内からの発表件数よりも世界各国からの件数が上回っ ており, 国際色が一層強くなっている䨌囲気があった。な お，日本からも 7 名が参加（図 2）し，6 件の論文発表をお こなったが，ブラジル国外からの参加国の中では 1 番多い 発表件数であった。招待講演および一般講演では, 日本に おける過去の雷研究の成果（データ，事例）を活用してい る報告が多々あり, 日本の耐雷研究の歴史やレベルの高さ をあらためて認識した。

その他のプログラムとして, SIPDA FOOTBALL CUPや City Tour, Symposium Dinner 等がおこなわれた。第 2 回 目となるSIPDA FOOTBALL CUPは, 白熱した国別対抗 の試合となり, 日本チームは惜しくも最下位であった。な お, 次回の SIPDA は 2011 年 8 月 8〜12 日にリオデジャネ イロで開催される予定である。雷研究の情報交換は当然の ことながら, サッカーを通じて国際的な親睦を深めること ができる珍しい国際会議であることから, サッカー好きの 研究者, 体力に自信のある若手研究者には是非, 参加をお 勧めしたい。

佐藤 智之 $[$ 財 $)$ 電力中央研究所 (平成 22 年 3 月 16 日受付) 